\title{
(6) OPEN ACCESS \\ 'It will harm business and increase illicit trade': an evaluation of the relevance, quality and transparency of evidence submitted by transnational tobacco companies to the UK consultation on standardised packaging 2012
}

\author{
K A Evans-Reeves, J L Hatchard, A B Gilmore
}

Tobacco Control Research Group and member of UK Centre for Tobacco and Alcohol Studies, University of Bath, Bath, UK

\section{Correspondence to} Dr Karen Evans-Reeves, Tobacco Control Research Group, University of Bath, The Avenue, Claverton Down, Bath BA2 7AY UK: k.a.evans-reeves@bath.ac.uk

Received 28 July 2014 Accepted 29 October 2014 Published Online First 3 December 2014

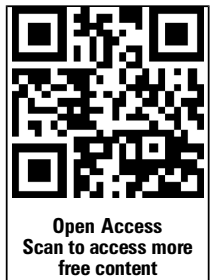

CrossMark

To cite: Evans-Reeves $K A$, Hatchard JL, Gilmore AB. Tob Control 2015;24: e168-e177.

\section{ABSTRACT}

Introduction Transnational tobacco companies (TTCS) submitted evidence to the 2012 UK Consultation on standardised packaging (SP) to argue the policy will have detrimental economic impacts and increase illicit tobacco trade.

Methods A content analysis of the four TTC submissions to the consultation assessed the relevance and quality of evidence TTCs cited to support their arguments. Investigative research was used to determine whether the cited evidence was industry connected. Fisher's exact tests were used to compare the relevance and quality of industry-connected and independent from the industry evidence. The extent to which TTCs disclosed financial conflicts of interest (COI) when citing evidence was examined.

Results We obtained 74 pieces of TTC-cited evidence. The quality of the evidence was poor. TTCs cited no independent, peer-reviewed evidence that supported their arguments. Nearly half of the evidence was industry-connected $(47 \%, 35 / 74)$. None of this industryconnected evidence was published in peer-reviewed journals (0/35) and $66 \%(23 / 35)$ of it was opinion only. Industry-connected evidence was of significantly poorer quality than independent evidence $(p<0.001)$. COls were not disclosed by TTCs in 91\% (32/35) of cases.

Conclusions In the absence of peer-reviewed research to support their arguments, TTCs relied on evidence they commissioned and the opinions of TTC-connected thirdparties. Such connections were not disclosed by TTCS when citing this evidence and were time consuming to uncover. In line with Article 5.3 of the Framework Convention on Tobacco Control and broader transparency initiatives, TTCs should be required to disclose their funding of all third-parties and any COIs when citing evidence.

\section{INTRODUCTION}

Transnational tobacco companies (TTCs) have vehemently opposed proposals for the introduction of standardised packaging (SP) for tobacco products in the UK, ${ }^{1-9}$ as they have in other countries where governments have attempted to introduce this policy. ${ }^{10-15}$ In submissions to the Department of Health's 2012 consultation on this issue, TTCs argued the policy would have unintended negative economic consequences, including a detrimental impact on retailers, manufacturers and the exchequer, and an increase in the illicit tobacco trade. ${ }^{1-4} 8{ }^{16}$ Leaked Philip Morris International (PMI) documents, which outlined the company's plans to prevent SP in the UK, confirm that the company planned widespread dissemination of these arguments to the public and to decision makers to promote their main message that the government's 'focus needs to be on economy and growth'. ${ }^{17} 18$

Such economic arguments can be powerfully used under the framework of Better Regulation (BR), introduced from the mid-1990s across jurisdictions globally, including the EU and UK. Better, or smart, regulation aims to improve policy-making by increasing the role of evidence in policy-making as well as formalising opportunities for affected interests to be consulted. ${ }^{19}$ However, BR has increasingly become a system for reducing regulation and enhancing business competitiveness. ${ }^{19} 20$ In the UK, government guidelines on BR now make it explicit that regulation should not 'impose costs' on business 'unless a ... compelling case has been made'. ${ }^{21}$ Impact Assessment and stakeholder consultation, the tools through which potential costs and benefits of proposed regulation ${ }^{22}$ are assessed, give corporations an explicit role in assessing and contesting the evidence for a policy. ${ }^{23}$ Previous research suggests that the use of a cost benefit approach to impact assessment used within this system confers advantages on well-resourced companies seeking to oppose regulations that threaten their profits. ${ }^{24}$ British American Tobacco (BAT) played an instrumental role in embedding BR tools into EU policy-making, anticipating that they would make it harder to pass public health policies. ${ }^{25}$

In light of the above, TTCs' long-standing history of manipulating evidence in their own inter$\mathrm{est}^{26-33}$ is of particular concern. We have already shown that the evidence used by TTCs in their submissions to argue that SP will not reduce smoking uptake was of low quality, ${ }^{8}$ and TTCs repeatedly misquoted and distorted the main messages of published studies. ${ }^{9}$ TTCs' misuse of illicit trade and economic arguments has been well documented. ${ }^{34} 35$ Their claims that SP would increase the illicit trade in tobacco in Australia and lengthen transaction times, because generic packets would take longer for sales staff to locate, have been roundly refuted by emerging evidence. ${ }^{36-39}$

The situation is further complicated by TTCs' growing use of the third-party technique: using a seemingly independent messenger with a better 
reputation and greater credibility to convey arguments. ${ }^{40}$ Previous efforts by TTCs have included hiring independent organisations and experts, creating front groups and establishing alliances with lobby groups and other industries to campaign on their behalf. $^{25}{ }^{41-43}$ The aforementioned PMI leaked documents also reveal that third-parties were to play a central role in disseminating its economic and illicit trade arguments against SP. ${ }^{17} 18$

This paper therefore aims to assess the quality and relevance of the evidence that TTCs cited in their submissions to the UK's 2012 consultation on SP to argue that the policy would lead to negative economic impacts and an increase in the illicit tobacco trade. It also examines the degree to which TTCs cite 'evidence' from those with TTC connections (ie, third-parties) and how transparent TTCs are about these connections in their written submissions. The UK Intellectual Property Office's guidance on standards of evidence used in the development of policy state: "An important part of public policy-making is transparency. It should be made clear who has commissioned and funded the research as well as who has carried it out." 44 This is compatible with principle 3 of Article 5.3 of the Framework Convention on Tobacco Control: "Parties should require the tobacco industry and those working to further its interests to operate and act in a manner that is accountable and transparent." 45

\section{METHODS}

\section{Data}

Consultation submissions were obtained, via company websites, for the four TTCs operating in the UK-Imperial Tobacco, Japan Tobacco International (JTI), BAT and PMI. Every citation (hereafter referred to as evidence) made in each TTC submission to support arguments on alleged illicit trade and economic impacts of SP was recorded. In line with questions asked in the Department of Health's Impact Assessment, ${ }^{46}$ we defined economic evidence as that which discussed: production and distribution costs to manufacturers, costs to retailers and the public relating to transaction times, or costs to the exchequer through loss of tobacco duty. Arguments that concerned economics but focused on individual behavioural impacts, for example, that SP will lead to increased price competition and therefore increased consumption, were excluded. Illicit trade evidence was any citation used to argue that SP would impact on the illicit tobacco trade.

Unlike our previous work, where we recorded only formal written evidence cited, ${ }^{8}$ the scant use of formal evidence and substantially greater use of informal evidence such as press coverage and individual commentaries on economic/illicit issues meant that we interpreted evidence broadly. We included all economic/illicit 'evidence' referred to in the text and cited in the bibliography of each TTC's submission in addition to quotes in the main text that were attributed to individuals or organisations but not formally cited. Where more than one company had cited identical evidence it was only counted once.

\section{Analysis}

Copies of evidence cited by TTCs were obtained and for each, the author, title, date and source were recorded in an Excel spreadsheet. The quality of the evidence and its relevance to SP was assessed using criteria based on existing literature in this field. ${ }^{8} 27$ 47-51 Additional categories were developed to allow for the generally low quality of the evidence (table 1).

\section{Quality}

Evidential quality was assessed using three criteria: independence from the tobacco industry, nature of the evidence and publication route (table 1$)$.
Independence: For each piece of evidence cited, the TTC's submission was searched for a funding or a conflict of interest (COI) statement. If no disclosure was found, we noted that the TTC had not declared any financial relationship between themselves and the authors of the cited evidence. At this stage, to clarify whether the evidence was either connected or independent of industry, each piece of evidence was searched for a funding or COI statement. If none was present within the evidence document itself then a further series of checks was performed (see figure 1). Evidence was categorised as independent of the tobacco industry if it included a clear funding statement that did not mention tobacco industry funding or if further internet searches revealed no relationship existed between the author and any tobacco company. Evidence was categorised as industry-connected if there was evidence of a financial relationship between its author (whether individual or organisational) and one or more TTC. The degree of financial relationship varied on a continuum from complete to part funding (table 1).

As space precludes us from providing full details of the industry-connected organisations and individuals identified during the course of this research, these are available on our website, http://www.TobaccoTactics.org.

The nature of the evidence was categorised as either research (eg, interviews, surveys, observational studies, experimental studies, systematic reviews, literature reviews and critiques), statistics or facts with no opinion expressed (eg, presentation of data without the underlying methodological detail found in research studies), opinion (including those with some supporting evidence ranging from referenced evidence, data, figures, to casual references to 'the evidence' and those that made no attempt to refer to any evidence in either a formal or casual capacity), or strategy documents (primarily outlining a plan of action, including a combination of research, opinions, and/or facts and figures; table 1).

Publication route was categorised to account for the diversity of evidence. Although peer-reviewed studies are considered to be superior quality evidence, ${ }^{52}$ many other forms are also submitted to, and considered in, public consultations. ${ }^{53-57}$ Our categorisation included peer-reviewed journals and other academic outlets, official government publications, official parliamentary publications, publication by private companies and organisations, and those published by the press (table 1).

\section{Relevance}

To determine its relevance to SP policy, the subject matter of each piece of evidence was recorded. Evidence was coded as 'highly relevant' if it was about illicit trade or economic impacts (see above) and tobacco packaging, standardised or otherwise. Evidence about illicit trade or economic issues but not packaging was coded as 'less relevant' to SP regulation. ${ }^{8}$

Evidence was coded by two researchers (KAER and JH) with 94\% concordance. All discrepancies were resolved.

Following categorisation of the evidence, we compared the relevance and quality of the evidence connected to and independent of industry using two-tailed Fisher's exact tests. The measures of quality used for this analysis were the nature of the evidence and publication route. For nature of the evidence we combined research, publication of facts and statistics, and strategy documents and compared these with opinion. For publication route, we combined articles published in peer-reviewed journals or other academic outlets along with official government and parliamentary publications and compared them with those published by private organisations or in the press. 
Table 1 Coding framework for classifying evidence

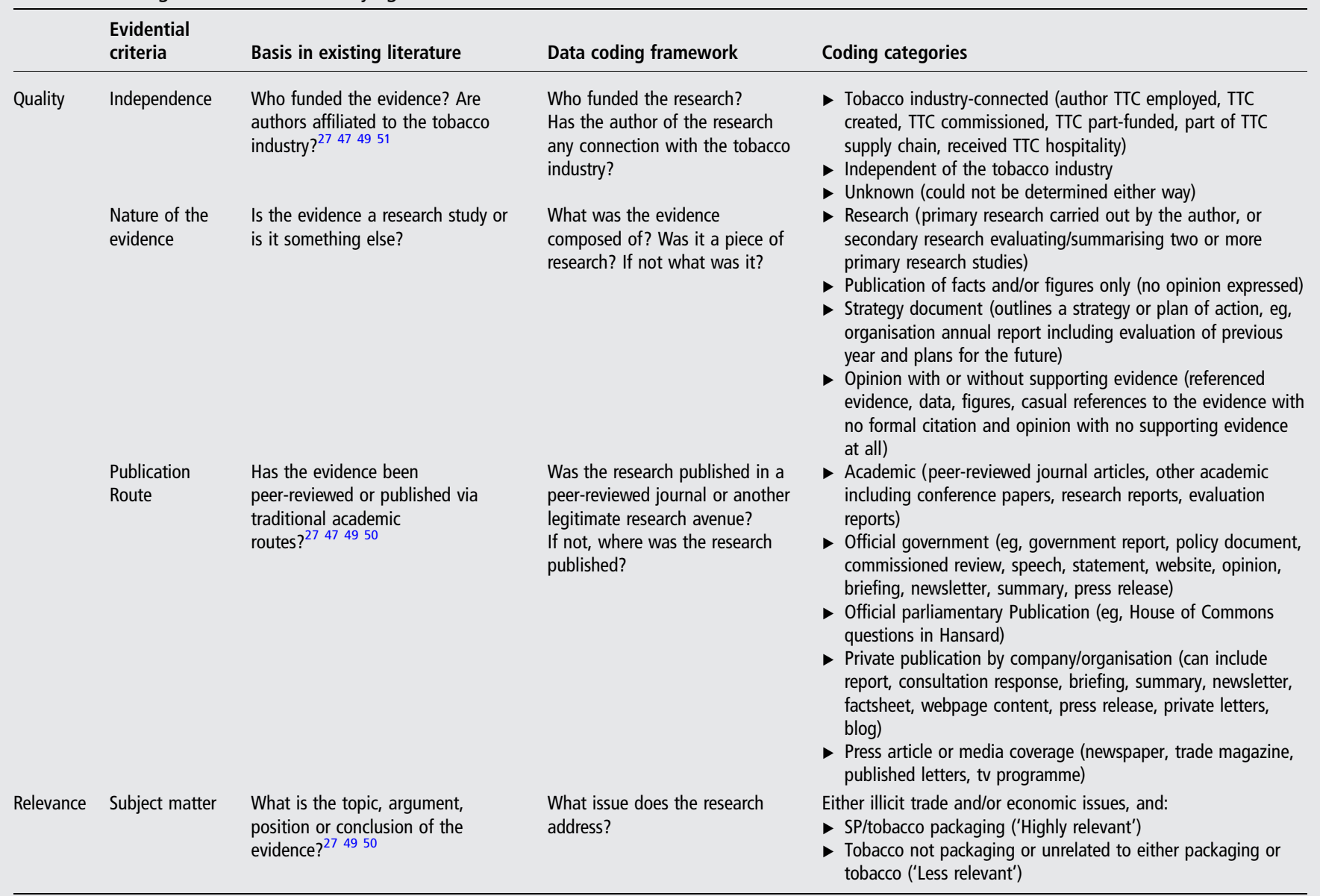

Table amended from Hatchard et al. ${ }^{8}$

SP, standardised packaging; TTC, transnational tobacco company.

Finally, for TTC-cited evidence coded as industry-connected, the number of instances where TTCs had disclosed this link in their submissions was recorded.

\section{RESULTS}

Imperial, JTI, BAT and PMI collectively cited 83 pieces of unique evidence to support illicit trade and economic arguments against SP. We were able to obtain $74 ; 11$ were predominantly about economic issues, 50 were about illicit issues, while 13 pieces of evidence referred to both. Examples of these arguments and the evidence used to support them are given in box 1 .

\section{Quality}

Overall, the quality of the cited evidence was very poor; this was particularly the case for industry-connected evidence (table 2).

\section{Independence}

Almost half of the evidence cited $(35 / 74,48 \%)$ was financially connected with the tobacco industry, while 51\% (38/74) was independent of the tobacco industry. For one piece of evidence it could not be determined either way.

\section{Nature of evidence}

Nearly half of the evidence consisted of opinion only $(45 \%$; $33 / 74$; table 2). A quarter (19/74) was research, 15\% (11/74) were strategy documents and a further $15 \%$ were facts and figures. The majority of industry-connected evidence was opinion $(23 / 35,66 \%)$, while the majority of the independent evidence $76 \%(29 / 38)$ comprised research, facts and figures or strategy documents (figure $2 \mathrm{~A}$ ). These differences in quality were highly significant $(p<0.001)$.

\section{Publication route}

Only 7\% (5/74) of the evidence was published in either a peerreviewed journal (2) or other academic outlet (3), while $46 \%$ (34/74) was privately published, $32 \%(24 / 74)$ came from official government or parliamentary sources and 15\% (11/74) was published in the press (table 2 ). The publication route of industryconnected and independent evidence differed significantly $(p<0.001)$. None of the industry evidence was peer-reviewed, the majority, 97\% (34/35), instead being published privately $(27 / 35)$ or in press articles (7/35; figure $2 \mathrm{~B})$. In contrast, $74 \%$ (28/38) of evidence independent of the tobacco industry was research, government or parliamentary publication.

\section{Relevance}

Of the 74 pieces of evidence obtained 42/74 (57\%) were relevant to either SP or packaging in general, 31/74 (42\%) about tobacco but not packaging and 1/74 (1\%) was unrelated to either packaging or tobacco. The odds of evidence being about packaging were 34 times higher if it was industry-connected $(32 / 35)$ compared to independent evidence $(9 / 38 ; \mathrm{p}<0.001$; figure $2 \mathrm{C})$. None of the independent, peer-reviewed evidence that TTCs cited were highly relevant to SP $(0 / 2)$. 


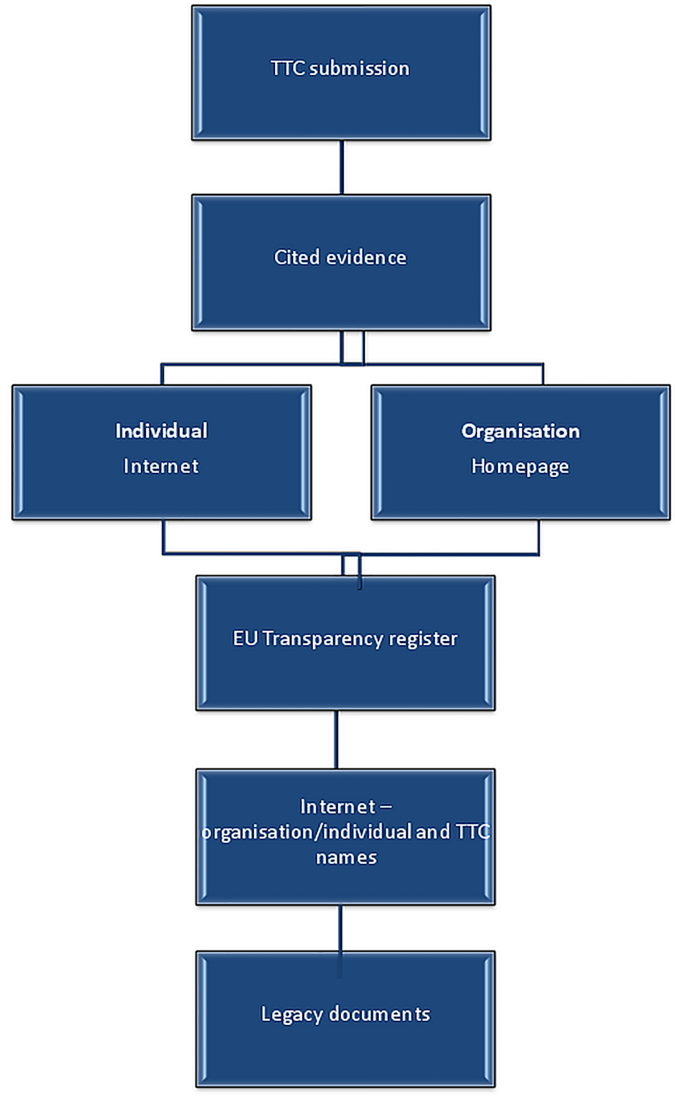

Figure 1 Procedure followed when searching for any conflict of interest between transnational tobacco companies (TTCS) and the individuals and organisations cited. Note: Could have changed the order of this procedure by searching immediately for organisations or individuals alongside the names of TTCs, or searching the legacy library. However, we were interested in how transparent TTCs, individuals and organisations were, and this provided justification for the order in which these searches were conducted.

\section{Transparency around industry-connected evidence}

In only 3 of 35 instances did TTCs declare their financial links to the organisations and individuals authoring the evidence they cited. In two of these instances this could not be avoided as JTI was actually the author.

TTCs did not disclose their links to the authors of the remaining 32/35 (91\%) pieces of evidence. The authors of this linked evidence were either TTC employed, created, commissioned, part-funded (eg, by membership fees), involved in the tobacco supply chain or in receipt of TTC hospitality (figure 3).

Only in two instances (two pieces of evidence authored by the Tobacco Manufacturers' Association-the TTCs' trade association in the $\mathrm{UK}^{58}{ }^{59}$ ) might readers be expected to identify the industry links. In all other instances, links to tobacco companies would have been difficult to identify. For example, TTCs cited two pieces of evidence from the Tobacco Retailers Alliance, ${ }^{60} 61$ without disclosing that it is a front group created and entirely financed by the Tobacco Manufacturers' Association. ${ }^{62} 63$ A further four pieces of cited evidence were authored by two organisations, the British Brands Group and the AntiCounterfeiting Group, ${ }^{64-67}$ both of which were originally created by one or more TTCs. ${ }^{7}{ }^{68-70}$ Although all four TTCs cited evidence from the British Brands Group, neither Imperial Tobacco, BAT nor PMI disclosed that they were members. However, it must be noted that JTI, which is not a member, did
Box 1 Transnational tobacco companies (TTCs) use of evidence to support economic and illicit arguments against standardised packaging

\section{Negative economic consequences}

"The Tobacco Retailers Alliance UK, a coalition of 26000 independent shopkeepers who sell tobacco products, has warned its members that: '.. .banning cigarette branding would directly threaten small shops. For many of you, tobacco sales make up around a third of turnover, sometimes more. ... . During the busy times, such as the morning rush, there is a real risk that customers who have to wait will go to supermarkets and larger shops, which have more staff and therefore shorter transaction times."'[British American Tobacco, ${ }^{4}$ 2012 citing evidence from the Tobacco Retailers Alliance] ${ }^{61}$

In its submission BAT does not disclose that the Tobacco Retailers Alliance is funded by the Tobacco Manufacturers' Association, which in turn is entirely funded by three TTCS, including BAT. ${ }^{62} 63$

Two reports prepared by Deloitte for the Alliance of Australian Retailers $^{72} 73$ suggest that retailing times would be adversely affected if standardised packaging were introduced by an additional 15 to 45 seconds per transaction and that the effect would be particularly significant for smaller retailers. [Imperial Tobacco, 2012]

In its submission, Imperial Tobacco does not disclose that the Alliance of Australian Retailers is a front group created and funded by PMI, Imperial and BAT and managed daily by PMI personnel. ${ }^{135}$

\section{Independent evidence finds that illicit tobacco trade will worsen}

"The expert opinion of Professors Zimmerman and Chaudhry is that plain packaging 'will worsen the illicit trade in tobacco products'. JTI shares this view." [Japan Tobacco International, 2012]

In its submission JTI does not disclose that it commissioned the Chaudhry and Zimmerman report. ${ }^{71}$

$$
\begin{aligned}
& \text { "Experts from law enforcement officers to academics have concluded } \\
& \text { that plain packaging will increase demand for illicit tobacco } \\
& \text { products. For example, plain packaging will likely cause an increase } \\
& \text { in the black market for smuggled branded tobacco according to } \\
& \text { nearly } 70 \% \text { of current UK police officers who responded to a recent } \\
& \text { survey" [Philip Morris, 2012] }
\end{aligned}
$$

In its submission PMI does not disclose that it commissioned the police officers survey ${ }^{76}$ or that the academics they cite therein have been commissioned to produce reports. Nor do they disclose that the two ex-law enforcement officers that they cite, Roy Ramm ${ }^{114}$ and Peter Sheridan, ${ }^{115}$ are co-founders of the Common Sense Alliance, which is funded, at least in part, by British American Tobacco. ${ }^{136}$

disclose in its submission that although it was not a member, other tobacco companies were.

TTCs cited seven research reports they had commissioned (see figure 3 for authors), but did not declare this fact in their submissions (a funding statement was included in each of the reports but this would require policymakers to access these reports directly in addition to reading each TTC submission). ${ }^{71-77}$ A further nine pieces of cited evidence were attributed to organisations in receipt of tobacco company funding (eg, with one or more fee-paying TTC members), which was not declared. ${ }^{78-92}$ This evidence included four opinion statements, two from two sets of business associations ${ }^{93}$ one from the International Chamber of 
Table 2 Number of TTC-cited pieces of evidence by relevance and quality (nature, publication route) and independence from the tobacco industry $(n=74)$

\begin{tabular}{|c|c|c|c|c|c|c|c|c|c|c|c|}
\hline \multirow[b]{2}{*}{$\begin{array}{l}\text { Quality indicators } \\
\text { Connection with industry }\end{array}$} & \multicolumn{2}{|l|}{ Relevance } & \multicolumn{3}{|c|}{ Nature of the evidence } & \multicolumn{5}{|c|}{ Publication route } & \multirow[b]{2}{*}{ Total } \\
\hline & Packaging & Other & Research & Opinion & Other & Peer-review & Academic other & $\begin{array}{l}\text { Official government/ } \\
\text { parliament }\end{array}$ & Private & Press & \\
\hline Independent & 9 & 29 & 10 & 9 & 19 & 2 & 2 & 24 & 6 & 4 & 38 \\
\hline Connected & 32 & 3 & 9 & 23 & 3 & 0 & 1 & 0 & 27 & 7 & 35 \\
\hline Unknown & 1 & - & - & 1 & - & - & - & - & 1 & - & 1 \\
\hline Total & 42 & 32 & 19 & 33 & 22 & 2 & 3 & 24 & 34 & 11 & 74 \\
\hline
\end{tabular}

Commerce (ICC) ${ }^{95}$ and one from its subsidiary, the ICC Business Action to Stop Counterfeiting and Piracy. ${ }^{96}$ Three press articles and one response to the Department of Health's 2008 Consultation on the Future of Tobacco Control cited the opinions of four different retail organisations, ${ }^{97-100}$ and a press release stating the opinion of Trade Union UNITE, ${ }^{101}$ whose members include TTC employees. ${ }^{102}$ TTCs did not disclose any links with these organisations when it cited this evidence.

Four pieces of evidence were authored by supply chain companies, two from packaging companies (who list TTCs as clients) $)^{103} 104$ and two from the European Carton Makers Association, ${ }^{105} 106$ an organisation representing the interests of packaging companies, including those making tobacco packaging. ${ }^{107} 108$ These links were not declared by tobacco companies in their submissions.

An open letter cosigned by 51 Members of Parliament to Health Secretary Andrew Lansley ${ }^{109}$ included seven signatories who had accepted hospitality from JTI. ${ }^{110}$ This link was also not declared by the citing tobacco company.

Finally, in three cases, the authors' links to the tobacco industry were more obscure. A report by Erik Bloomquist, an equity analyst at Berenberg Bank, was cited. ${ }^{111}$ This report credited tobacco industry consultant John Luik ${ }^{112}$ for his assistance. Plagiarism software, WCopyfind V.4.1.1, revealed that $73 \%$ of a report called 'Erasing intellectual property', authored by Luik and Patrick Basham, ${ }^{113}$ is replicated in Bloomquist's report. ${ }^{111}$ Given the known relationship between Patrick Basham, John Luik and TTCs, ${ }^{112}$ an indirect link between Bloomquist's report and the tobacco industry was assumed. Similarly the opinions of two former senior police officers, Roy Ramm and Peter Sheridan, were cited. ${ }^{114} 115$ However, it was not disclosed that both are cofounders of the Common Sense Alliance, an antiregulatory lobby group that receives financial support from BAT. ${ }^{136}$

\section{DISCUSSION}

\section{Key findings}

The evidence TTCs used to support their argument that SP would have adverse economic and illicit trade impacts was of very low quality. TTCs did not cite any independent, peerreviewed evidence that supported these arguments. Instead they relied on research they had commissioned ${ }^{69-75}$ or the opinions of those with varying degrees of financial links to the industry. Of the 35 industry-connected pieces of evidence, seven were research reports commissioned by TTCs or by a third-party financially connected to a TTC, and the majority of the remainder (23/35) were opinions of business and retail organisations with TTC members, packaging companies with TTC clients, a trade union with members who are TTC employees and MPs sympathetic to the industry position on SP, some of whom have taken TTC hospitality. Although nearly half of the evidence cited by TTCs was financially connected to them, the companies did not disclose this connection in $91 \%$ of cases and such connections were often time-consuming to discover.

\section{Limitations}

We set the parameters of this study to focus exclusively on the evidence TTCs used to support illicit trade and economic arguments (as defined in the Impact Assessment) ${ }^{46}$ and have not, therefore, examined all the evidence cited in their submissions to support all their arguments. Nor do we assess the accuracy of the TTCs' interpretation of the evidence cited. However, we have previously examined the quality and relevance of the evidence TTCs used to argue that SP will not reduce youth smoking uptake, ${ }^{8}$ and undertaken in depth analysis of how they interpreted evidence in their submissions, identifying a number of techniques used to misrepresent and distort evidence. ${ }^{9}$

As we were interested specifically in the quality of the evidence used by TTCs, we only counted unique pieces of evidence, although many were cited by more than one company and sometimes by all four. Finally, we were unable to identify industry links to three of the business organisations who co-authored, with other TTC-connected business organisations, opinion statements cited by the TTCs (ECAT, APRAM, UNION-IP; figure 3). The policy of private membership implemented by many business organisations made it difficult to determine any links. However, due to the financial links of the coauthors of these pieces of evidence, the individual pieces of evidence were coded as industry-connected.

\section{Discussion/links with previous evidence}

Our findings support previous research, which shows that, in response to regulatory proposals, evidence submitted by the tobacco industry has typically been less scientifically rigorous than the evidence cited by supporters of the regulation. ${ }^{115}$ They also add to a growing body of literature, which shows that, in order to oppose SP, TTCs cited poor quality, industry-funded evidence that purported to show the policy would not work ${ }^{8}$ and fundamentally misrepresented independent evidence supportive of the policy. ${ }^{9}$

In relation to illicit trade, our findings provide further evidence that TTC-commissioned data and evidence on illicit trade cannot be trusted. TTC data across a number of jurisdictions, including that commissioned from leading accountancy firms, have been shown to over-estimate the scale of the illicit trade, exaggerate the upward trend (including by revising historical figures downwards) or misrepresent the nature of the trade in order to down-play the extent of tobacco industry involvement. ${ }^{5}{ }^{118-123}$ The limited methodological detail available on the tobacco industry's empty pack surveys, which usually form the basis of these industry data, suggest they may be deliberately designed to exaggerate the extent 

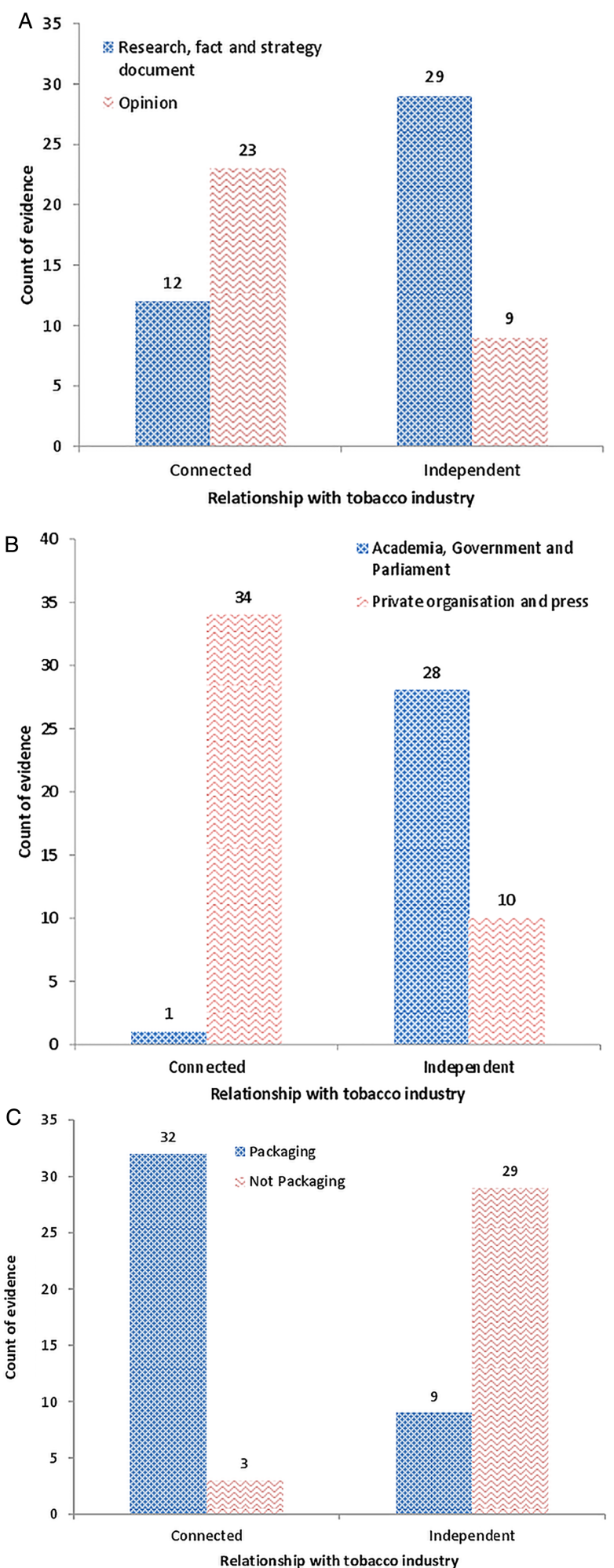

Figure 2 (A) Nature of the evidence by tobacco industry connection $\left(\mathrm{N}=73^{*}\right)$. (B) Publication route by tobacco industry connection $\left(\mathrm{N}=73^{*}\right)$. (C) Relevance of evidence by tobacco industry connection $\left(\mathrm{N}=73^{*}\right)$. *Note: $\mathrm{N}=73$ because one piece of evidence (relevant to private organisation and press) could not be classified as either connected or independent of the tobacco industry.

of the illicit trade. ${ }^{121}$ In a retreat following criticism of its previous data, ${ }^{121}$ KPMG's latest report for PMI has revised its illicit estimate for the UK illicit trade downwards stating "alternative data sources suggest this [the 2012 estimate] may have overstated non- domestic incidence for the full year". ${ }^{124}$ Industry claims that various policies, including SP, will fuel the illicit trade have been found to be highly misleading. ${ }^{34} 35125$ For example, following the introduction of SP in Australia, another KPMG report produced on behalf of PMI claimed there had been a dramatic increase in the illicit tobacco trade in the country. ${ }^{126}$ However, in addition to criticisms of its methodology, ${ }^{118}$ independent research found no evidence of increased illicit use. $^{39} 127$

Taken together, the absence of independent evidence, or even independent opinion, that SP will increase illicit trade revealed in this paper, the questionable veracity of industry-funded data, the fact that the industry's previous illicit trade predictions have not materialised and PMI's explicit intention to utilise the illicit trade argument to "ensure that PP [plain packaging] is not adopted in the UK", ${ }^{17}$ suggest that the illicit trade argument is being used as an industry tactic to discourage governments from pursuing further tobacco control policies.

The same is true of TTCs' claims that SP will have adverse economic consequences. Independent research has found no evidence to support industry predictions that small businesses in Australia would suffer from customers moving from small convenience stores to bigger supermarkets. ${ }^{39}$

TTCs extensive use of third-party voices as authors of the 'evidence' creates problems for policymakers trying to assess the reliability of evidence. Tobacco companies' failure to declare these COI in their 2012 consultation submissions demonstrates that, despite decades of criticism and a requirement for transparency in Article 5.3, TTCs continue to rely heavily on the third-party technique to disseminate their messages via those with more credible voices than their own. Furthermore, the number and nature of organisations and individuals cited creates the impression of a large, expert and seemingly unconnected cohort, all opposed to or concerned about SP. PMI's leaked SP-opposition strategy named many (46\%, 12/26 listed figure 3 ) of the individuals and organisations cited in the TTC submissions (in the context covered in this paper) as 'influencers' or 'media messengers' (figure 3). ${ }^{17}$ By naming these influencers and messengers and giving a timeline indicating when third-parties would issue press releases and reports, the documents imply that PMI may have had some degree of influence.

\section{Policy implications}

Our findings provide further evidence that BR is problematic for the development of tobacco control policy. Within this regulatory environment, stakeholders (including corporations) are granted an explicit role to provide new evidence and to contest existing evidence and data. However, inadequate COI disclosure requirements mean that BR fails to take account of TTCs' longstanding history of manipulating evidence to serve their own interests. In this instance, the BR framework has enabled TTCs to more effectively frame and use their misleading arguments. This has contributed to uncertainty about policy impacts and consequent regulatory delays. ${ }^{128-130}$ PMI recognised this potential in BR as is revealed in their leaked documents, ${ }^{17}$ while BAT predicted, in pushing for BR, that it would enable them to contest, delay and ultimately overturn policies. ${ }^{25}$ The BR agenda, particularly the requirement for stakeholder consultation, can be seen to directly undermine the purpose of Article 5.3 - to protect public health policies relating to tobacco control "from commercial or vested interests of the tobacco industry" 45 — and to legitimise TTCs' counter-argument that they ought to be involved in decisions that affect them. ${ }^{25} 131$

Given the findings of this paper, the requirements of Article 5.3 and the overwhelming evidence of the tobacco industry's misuse of evidence, the terms of their inclusion in stakeholder 


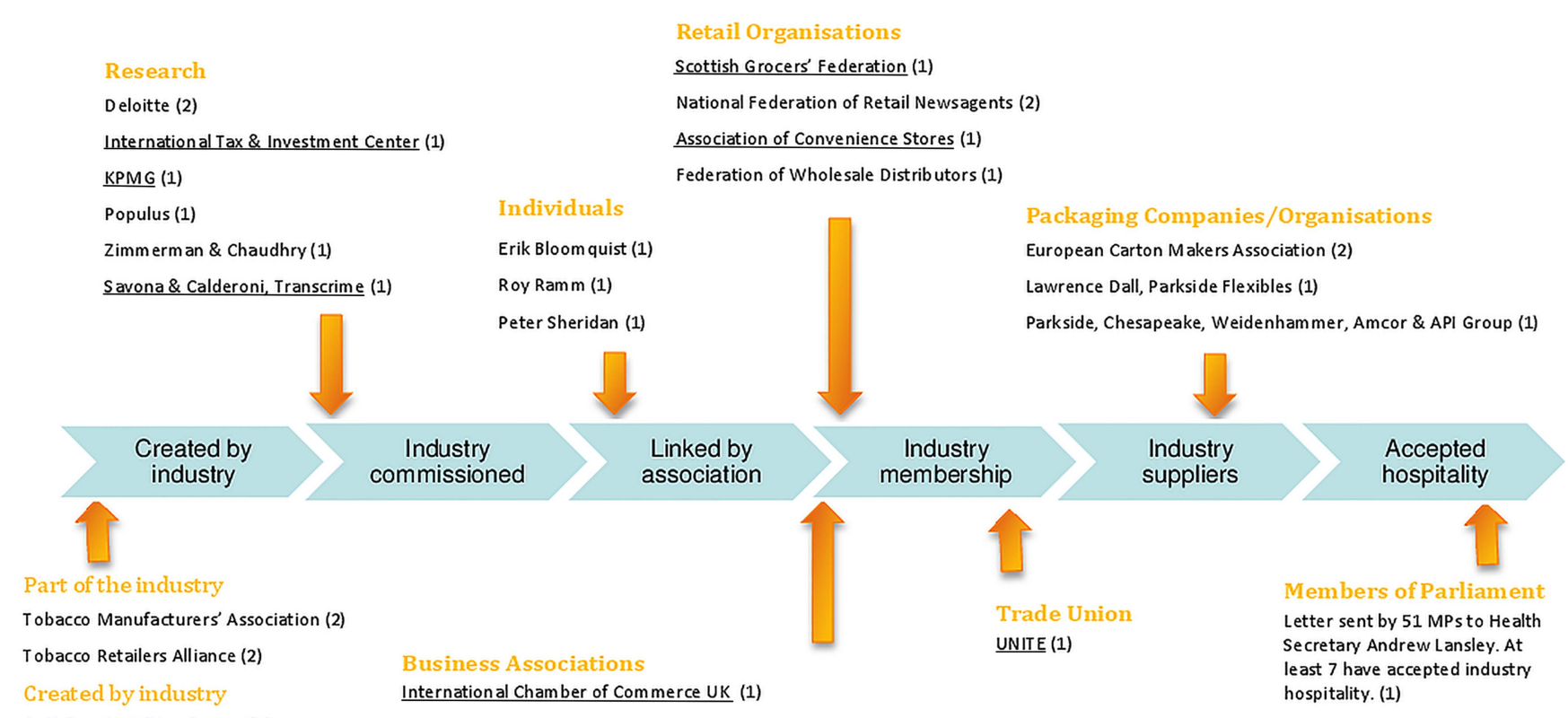

Anti-Counterfeiting Group (2)*

British Brands Group (3)*

International Chamber of Commerce UK's Business Action to Stop Counterfeiting \& Piracy (1)

₹US Chamber of Commerce, TransAtlantic Business Dialogue, Emergency Committee for American Trade,
National Association of Manufacturers, United States Council for International Business, \& National Foreign Trade Council (1)

๑Association des Praticiens du Droit des Marques et des Modeles, Beneluxverniging voor Merken en Modellenrecht, European Communities Trademark Association, German Association for the Protection of Intellectual Property, Marques, and Union IP (1)

Figure 3 Connection to Transnational Tobacco Companies (TTCs, N=32 pieces of evidence). Note: Numbers in parentheses refer to the number of unique references authored by the named organisation(s) or individual(s). Those underlined were identified by Philip Morris International as either 'influencers' or 'messengers'. ${ }^{17} 18$ t In the joint statement cited by these business associations, we were unable to determine whether the following business associations have TTC members: the Emergency Committee for American Trade. However, links were found between the remaining five authors. ${ }^{\circledR} 4 / 6$ of the business associations authoring this joint statement were industry-connected, however, we were unable to determine the existence of a link between Association des praticiens du droit des marques et des modèles (APRAM) or Union IP (an intellectual property organisation). *The Anti-Counterfeiting Group and British Brands Group are joint authors of two pieces of unique evidence.

consultation processes require some reassessment. If TTCs are allowed to continue to submit evidence to public consultations as part of BR, it should be compulsory for them, in line with 5.3 , to exercise transparency by disclosing any potential COI, not only of their own position, but also that of the evidence they use to build their case either for or against a policy proposal. Such disclosures are now standard practice when submitting research to health-related academic journals. ${ }^{132-134}$ Where TTCs are found to have omitted such disclosures, governments

\section{What this study adds}

- Our analysis reveals that transnational tobacco companies (TTCS) have cited no independent, peer-reviewed evidence that supports their case. Instead they relied on evidence they had commissioned and the opinions of TTC-connected third-parties, providing further evidence that TTCS exaggerate the threat of illicit tobacco and the negative economic consequences of policy as part of a deliberate strategy to ward off regulation.

- TTCs have not disclosed relevant conflicts of interest within their submissions, highlighting incompatibility between Better Regulation and Article 5.3 of the Framework Convention on Tobacco Control. should not be required to consider this evidence in their policy deliberations. Further, any data produced by industry on the illicit tobacco trade, or on those with whom it has a financial relationship, should be treated with extreme caution.

Correction notice This article has been corrected since it was published Online First. Gilmore and Hatchard's middle initials have been added to the author list.

Acknowledgements The authors would like to gratefully acknowledge the contributions of Eveline Lubbers, Andrew Rowell and Rachel Rose Jackson of the Tobacco Control Research Group at the University of Bath.

Contributors $A B G$ conceived the idea for the study. KAE-R and JLH gathered and analysed the data. KAE-R wrote the paper. ABG and JLH contributed to the writing of and edited the paper. All authors approved the final version.

Funding This work was supported by Cancer Research UK grant number C48078/ A16481 and ESRC grant number ES/L00206X. In addition AG is supported by the US National Cancer Institute Grant Number R01CA160695. The content is solely the responsibility of the authors and does not necessarily represent the official views of the National Cancer Institute or the National Institutes of Health. JH is funded by, and all authors are members of, the UK Centre for Tobacco and Alcohol Studies (UKCTAS), a UK Centre for Public Health Excellence. Funding to UKCTAS from the British Heart Foundation, Cancer Research UK, the Economic and Social Research Council, the Medical Research Council and the National Institute of Health Research, under the auspices of the UK Clinical Research Collaboration, is gratefully acknowledged.

Competing interests None.

Provenance and peer review Not commissioned; externally peer reviewed.

Data sharing statement The data used for this study were taken from publicly available documents and are therefore freely available. 
Open Access This is an Open Access article distributed in accordance with the terms of the Creative Commons Attribution (CC BY 4.0) license, which permits others to distribute, remix, adapt and build upon this work, for commercial use, provided the original work is properly cited. See: http://creativecommons.org/ licenses/by/4.0/

\section{REFERENCES}

1 Philip Morris Limited. Standardised tobacco packaging will harm public health and cost UK taxpayers billions: a response to the Department of Health consultation on standardised packaging of tobacco products. 2012.

2 Japan Tobacco International. Response to the Department of Health's consultation on the standardised packaging of tobacco products. 2012.

3 Imperial Tobacco. Bad for business; bad for consumers; good for criminals: Standardised packaging is unjustified, anti-competitive and anti-business. A response to the UK Department of Health consultation on standardised packaging of tobacco products. 2012.

4 British American Tobacco. UK standardised packaging consultation: Response of British American Tobacco UK Limited. 2012.

5 Sir Cyril Chantler. Standardised packaging of tobacco. Report of the independent review undertaken by Sir Cyril Chantler. April 2014. http://www.kcl.ac.uk/health/ 10035-TSO-2901853-Chantler-Review-ACCESSIBLE.PDF (accessed 10 May 2014).

6 Tobacco Control Research Group. Corporate political advertising on plain packaging. University of Bath. Last modified 1 November 2013. http://www. tobaccotactics.org/index.php/Corporate_Political_Advertising_on_Plain_Packaging (accessed 23 Jul 2014).

7 Action on Smoking and Health. The smoke filled room: How big tobacco influences health policy in the UK. 2010. http://www.ash.org.uk/SmokeFilledRoom (accessed 21 Jul 2014)

8 Hatchard JL, Fooks G, Evans-Reeves KA, et al. A critical evaluation of the volume, relevance and quality of evidence submitted by the tobacco industry to oppose standardised packaging of tobacco products. BMJ Open 2014;4: e003757.

9 Ulucanlar S, Fooks G, Hatchard JL, et al. How transnational tobacco companies mis-use scientific evidence: a review of tobacco industry submissions to the UK government consultation on standardised packaging. PLoS Med 2014;11: e1001629.

10 Owen J. Letter from John Owen of Wills New Zealand, to D Bacon regarding copy of the tobacco control regulations. 22 January 1993. British American Tobacco Collection. Bates No: 502610649-502610651. http://legacy.library.ucsf.edu/tid/ tas48a99 (accessed 23 Jul 2014).

11 Tobacco Institute of New Zealand Limited. Protection of intellectual property: Initial report and backgrounder. 10 May 1993. British American Tobacco Collection. Bates No: 502562991-502563006. http:/llegacy.library.ucsf.edu/tid/xla36a99 (accessed 23 Jul 2014).

12 Smithson J. Letter from public affairs manager Jaqueline Smithson to 'Plain Pack Group members'. Canada — update on plain pack initiatives by government. 10 March 1994. British American Tobacco Collection. Bates No: 502592796 502592798. http://legacy.library.ucsf.edu/tid/kyd28a99 (accessed 23 Jul 2014).

13 RJ Reynolds Tobacco Company. Plain packaging of tobacco product submission of RJ Reynolds tobacco company to the Standing Committee on Health, House of Commons Ottawa, Canada. 30 July 1993. R. Reynolds Collection. Bates No: 520777925-520777985. http://legacy.library.ucsf.edu/tid/mrm97c00/pdf (accessed $23 \mathrm{Jul}$ 2014)

14 Riordan M. Generics rejected by Australian Health. 24 July 1995. British American Tobacco Collection. Bates No: 800190578-800190582. http://legacy.library.ucsf. edu/tid/mrb81a99 (accessed 23 Jul 2014).

15 Liberman J. Plainly consitutional: the upholding of plain tobacco packaging by the High Court of Australia. Am J Law Med 2013;39:361-81.

16 Tobacco Control Research Group. Industry arguments against plain packaging. University of Bath. Last modified 26 June 2014. http://www.tobaccotactics.org/ index.php/Industry_Arguments_Against_Plain_Packaging (accessed 23 Jul 2014).

17 Philip Morris International. Leaked Document: UK Corporate Affairs Update February 2012.

18 Philip Morris International. Leaked Document: UK Corporate Affairs Update March 2012.

19 Radaelli CM, Meuwese ACM. Better Regulation in Europe: between public management and regulatory reform. Public Adm 2009;87:639-54.

20 Gibbons M, Parker D. Impact assessments and better regulation: the role of the UK's Regulatory Policy Committee. Public Money Manag 2012;32:257-64.

21 Better Regulation Delivery Office. Better regulation framework manual. Department for Business Innovation \& Skills. London, 2013.

22 HM Treasury. The green book: appraisal and evaluation in central government. HM Treasury London, 2011.

23 Gibbons M. Improving regulation: an independent report on the analysis supporting regulatory proposals January-December 2011 (Foreword). 2012.
24 Smith KE, Fooks G, Collin J, et al. Is increasing policy use of Impact Assessment in Europe likely to undermine efforts to achieve healthy public policy? I Epidemiol Community Health 2010;64:478-87.

25 Smith KE, Fooks G, Collin J, et al. "Working the System"—British American Tobacco's influence on the European Union Treaty and its implications for policy: an analysis of internal tobacco industry documents. PLOS Med 2010;7:e1000202.

26 Bero L. Tobacco industry manipulation of research. Public Health Rep 2005:120:200-8.

27 Bero L, Montini T, Bryan-Jones K, et al. Science in regulatory policy making: case studies in the development of workplace smoking restrictions. Tob Control 2001:10:329-36.

28 Francis JA, Shea AK, Samet JM. Challenging the epidemiologic evidence on passive smoking: tactics of tobacco industry expert witnesses. Tob Control 2006;15:68-76.

29 Gruning T, Gilmore A, McKee M. Tobacco industry influence on science and scientists in Germany. Am J Public Health 2006;96:20-32.

30 Hirschhorn N. Shameful science: four decades of the German tobacco industry's hidden research on smoking and health. Tob Control 2000;9:242-7.

31 Ong E, Glantz S. Constructing "sound science" and "good epidemiology": Tobacco, lawyers and public relations firms. Am J Public Health 2001;91:1749-57.

32 Tong EK, Glantz S. Tobacco industry efforts undermining evidence linking secondhand smoke with cardiovascular disease. Circulation 2007;116: 1845-54.

33 Ong E, Glantz $\mathrm{S}$. Tobacco industry efforts subverting international agency for research on cancer's second-hand smoke study. Lancet 2000;355:1253-9.

34 Gilmore A, Reed H. The truth about cigarette price increases in Britain. Tob Control 2013;23:e15-16.

35 Smith KE, Savell E, Gilmore A. What is known about tobacco industry efforts to influence tobacco tax? Tob Control 2013;22:e1.

36 Carter OBJ, Mills BW, Phan T, et al. Measuring the effect of cigarette plain packaging on transaction times and selection errors in a simulation experiment. Tob Control 2012:21:572-7.

37 Carter OBJ, Welch M, Mills BW, et al. Plain packaging for cigarettes improves retail transaction times. BMJ 2013;346:11063.

38 Hoek J, Vaudrey R, Gendall P, et al. Tobacco retail displays: a comparison of industry arguments and retailers' experiences. Tob Control 2012;21:497-501.

39 Scollo M, Zacher M, Durkin S, et al. Early evidence about predicted unintended consequences of standaridzed packaging of tobacco products in Australia: a cross-sectional study of place of purchase, regular brands and use of illicit tobacco. BMJ Open 2014;4:e005873.

40 Cave T, Rowell A. A quiet word: loobying, crony capitalism and broken politics in Britain. London: Bodely Head, 2014.

41 Proctor RN. Golden Holocaust: origins of the cigarette catastrophe and the case for abolition. Berkeley: University of California Press. 2011.

42 Appollonio $D E$, Bero $L$. The creation of industry front groups: the tobacco industry and "Get Government Off Our Back". Am J Public Health 2007:97:419-27.

43 Drope J, Chapman S. Tobacco industry efforts at discrediting scientific knowledge of environmental tobacco smoke: a review of internal industry documents. J Epidemiol Community Health 2001;55:588-94.

44 Intellectual Property Office. Good evidence for policy. 2011. http://www.ipo.gov. uk/consult-2011-copyright-evidence.pdf (accessed 19 Nov 2013).

45 World Health Organization. Guidelines for implementation of Article 5.3 of the WHO Framework Convention on Tobacco Control on the protection of public health policies with respect to tobacco control from commercial and other vested interests of the tobacco industry. 2003. http://www.who.int/fctc/guidelines/article 5_3.pdf (accessed 29 Oct 2013).

46 Department of Health. Consultation stage impact assessment questions. Department of Health: London: 2012.

47 Scollo M, Lal A, Hyland A, et al. Review of the quality of studies on the economic effects of smoke-free policies on the hospitality industry. Tob Control 2003;12:13-20.

48 Siegel M. Economic impact 100\% smoke-free restaurant ordinances., in Smoking and restaurants: A guide for policy makers. 1992, UC Berkeley/UCSF Preventative Medicine Residency Program; American Heart Association, California Affiliate; Almaeda County Health care Services Agency, Tobacco Control Program: Berkeley.

49 Montini T, Mangurian C, Bero LA. Assessing the evidence submitted in the development of a workplace smoking regulation: the case of Maryland. Public Health Reports 2002;117:291-8.

50 Barnes DE, Bero L. Scientific quality of original research articles on environmental tobacco smoke. Tob Control 1997;6:19-26.

51 Barnes DE, Bero LA. Industry-funded research and conflict of interest: an analysis of research sponsored by the tobacco industry through the center for indoor air research. J Health Polit Policy Law 1996;21:515-42.

52 National Institute for Health and Clinical Excellence. Guideline development methods: information for national collaborating centres and guideline developers. National Institute for Health and Clinical Excellence London: 2004. http://www. nice.org

53 Nutley SM, Walter I, Davies HTO. Using evidence: how research can inform public services. Bristol: The Policy Press, 2007. 
54 Strydom WF, Hill L, Eloff E. The role of communication in governance: the river health programme as a case study, In: Turton AR, ed. Governance as a trialogue: government society science in transition. Berlin: Springer-Verlag, 2007, pp281-304.

55 Davies P. Is evidence-based government possible? Jerry Lee Lecture. Washington DC. In 4th annual campbell collaboration colloquium. Policy Hub, UK Cabinet Office, 2004.

56 Day P. The media and the scientific message. J Health Serv Res Policy 1997:2:65-6.

57 Davies HTO, Nutley SM. Evidence-based policy and practice: moving from rhetoric to reality. In Third International, Inter-disciplinary Evidence-based Policies and Indicator Systems Conference. Durham, 2001.

58 Fenton, B. Sizing the non-duty paid market. Tobacco Manufacturers' Association. 2011 http://web1. wisetigerhosting.co.uk/ thetma/wp-content/uploads/2011/03/ TMA2.pdf (accessed 18 November 2014)

59 Cogent SSC. TMA fact sheet: The UK tobacco sector. Tobacco Manufacturers Association. May 2012

60 Tobacco Retailers Alliance. Campaigning: Retailers against smuggling. n.d.; http:/l www.tralliance.org.uk/index.php?option $=$ com content\&view $=$ article\&id $=29 \&$ Itemid=24 (accessed 12 Jun 2013).

61 Tobacco Retailers Alliance. Newsletter: Party conferences special. November 2011. http://www.tobaccoretailersalliance.org.uk/images/pdf/tra\%20Nov\%202011.pdf (accessed 21 Jul 2014).

62 Tobacco Control Research Group. Tobacco Manufacturers' Association. University of Bath. Last modified 30 June 2014. http://tobaccotactics.org/index.php/Tobacco_ Manufacturers\%27_Association (accessed 21 Jul 2014).

63 Tobacco Control Research Group. Tobacco Retailers' Alliance. University of Bath. Last modified 31 January 2014. http://www.tobaccotactics.org/index.php/Tobacco_ Retailers\%27_Alliance

64 Anti-Counterfeiting Group and British Brands Group. Standardised "plain" packaging -A leap in the dark. 16 April 2012. http://www.prnewswire.co.uk/ news-releases/standardised-plain-packaging---a-leap-in-the-dark-147572055.html (accessed 12 Jun 2013).

65 Anti-Counterfeiting Group and British Brands Group. Plain packaging: Unforeseen consequences. A briefing for the All Party Groups on Health Disease and Smoking \& Health. 2012. http://www.britishbrandsgroup.org.uk/upload/File/Briefing\% 20APPGs\%20ACG\%20BBG\%200112.pdf (accessed 21 Jul 2014).

66 Chapman M. Tobacco branding debate: Reaction from all sides. 2012. http://www. marketingmagazine.co.uk/article/1126883/tobacco-branding-ban-debate-reactionsides (accessed 21 Jul 2014).

67 Hands Off Our Packs. Campaign Blog. John Noble: Beware "full implications" of plain packs. 16 May 2012. http://www.handsoffourpacks.com/blog/ john-noble-beware-full-implications-of-plain-packaging/ (accessed 12 Jun 2013).

68 Tobacco Control Research Group. British Brands Group. University of Bath. Last modified 18 June 2014. http://tobaccotactics.org/index.php/British_Brands_Group (accessed $21 \mathrm{Jul}$ 2014).

69 BATco. Marketing News. 1981. British American Tobacco Collection. Bates No: 202007691-202007715. http://legacy.library.ucsf.edu/tid/mfo08a99/pdf; jsessionid=227DCA6819B038DF4AAFD4E92F9C3B11.tobacco03 (accessed $21 \mathrm{Jul}$ 2014).

70 Tobacco Control Research Group. Anti-Counterfeiting Group. University of Bath. Last modified 18 June 2014. http://tobaccotactics.org/index.php/ Anti-Counterfeiting_Group (accessed 21 Jul 2014).

71 Chaudhry P, Zimmerman A. The impact of plain packaging on the illicit trade in tobacco products. 2012. http://www.jti.com/files/5113/4150/5828/Impact_on_ illicit_trade.pdf (accessed 21 Jul 2014).

72 Deloitte. Potential impact on retailers from the introduction of plain tobacco packaging. 2011. https://www.australianretailers.com.au/downloads/pdf/deloitte/ 20110131 AAR_Plain Packaging2.pdf (accessed 21 Jul 2014).

73 Deloitte. Plain packaging and channel shift. 2011. https://www.australianretailers. com.au/downloads/pdf/deloitte/Potential_impact_of_channel_shift.pdf (accessed 21 Jul 2014)

74 International Tax and Investment Center. The illicit trade in tobacco products and how to tackle it. 2011. http://www.kangaroogroup.eu/DB_beelden/booklet_illicit_ trade_tobacco_products.pdf (accessed 21 Jul 2014).

75 KPMG. Project Star 2011 Results, Private and Confidential, For release pursuant to EC Regulation 1049/2001. 24 May 2011

76 Populus. A Survey of UK Law Enforcement: Views on Illegal Tobacco and Plain Packaging. June 2012. http://www.populus.co.uk/Poll/UK-Law-Enforcement-Viewson-Illegal-Tobacco-and-Plain-Packaging-1/ (accessed 21 Jul 2014).

77 Transcrime. Plain packaging and illicit trade in the UK: Study on the risks of illicit trade in tobacco products as unintended consequences of the introduction of plain packaging in the UK. 2012. Transcrime, Joint Research Centre on Transnational Crime. http://transcrime.cs.unitn.it/tc/fso/pubblicazioni/AP/Transcrime-Plain_ packaging_and_illicit_trade_in_the_UK.pdf (accessed 1 Aug 2012).

78 Tobacco Control Research Group. International Chamber of Commerce. University of Bath. Last modified 21 July 2014. http://www.tobaccotactics.org/index.php/ International_Chamber_of_Commerce (accessed 23 Jul 2014).
79 Tobacco Control Research Group. Federation of Wholesale Distributors. University of Bath. Last modified 21 November 2013. http://www.tobaccotactics.org/index. php/Federation_of_Wholesale_Distributors (accessed 17 Jun 2013).

80 Tobacco Control Research Group. National Federation of Retail Newsagents. University of Bath. Last modified 22 October 2013. http://www.tobaccotactics.org/ index.php/National_Federation_of_Retail_Newsagents (accessed 17 Jun 2013).

81 Tobacco Control Research Group. Scottish Grocers' Federation. University of Bath. Last modified 24 February 2014. http://www.tobaccotactics.org/index.php/ Scottish_Grocers\%27_Federation (accessed 17 Jun 2013).

82 Tobacco Control Research Group. UNITE. University of Bath. Last modified 24 July 2014. http://www.tobaccotactics.org/index.php/UNITE (accessed 24 Ju 2014).

83 Tobacco Control Research Group. US Chamber of Commerce. University of Bath. Last modified 24 July 2014. http://www.tobaccotactics.org/index.php/US_ Chamber of Commerce (accessed 24 Jul 2014).

84 Tobacco Control Research Group. Association of Convenience Stores. University of Bath. Last modified 28 November 2013. http://www.tobaccotactics.org/index.php/ Association_of_Convenience_Stores (accessed 19 Jun 2014).

85 Tobacco Control Research Group. National Foreign Trade Council. University of Bath. Last modified on 24 July 2014. http://www.tobaccotactics.org/index.php/ National_Foreign_Trade_Council

86 Tobacco Control Research Group. European Communities Trademark Association. University of Bath. Last modified 1 July 2014. http://www.tobaccotactics.org/index. php/European_Communities_Trademark_Association (accessed 22 Jul 2014).

87 Tobacco Control Research Group. MARQUES. University of Bath. Last modified 1 July 2014. http://www.tobaccotactics.org/index.php/MARQUES (accessed 22 Jul 2014).

88 Tobacco Control Research Group. German Association for the Protection of Intellectual Property. University of Bath. Last modified 6 June 2014. http://www. tobaccotactics.org/index.php/German_Association_for_the_Protection_of_ Intellectual_Property (accessed 22 Jul 2014).

89 Tobacco Control Research Group. United States Council for International Business. University of Bath. Last modified 26 June 2013. http://www.tobaccotactics.org/ index.php/United_States_Council_for_International_Business (accessed 22 Jul 2014).

90 Tobacco Control Research Group. Beneluxvereniging voor Merken-en Modellenrecht. University of Bath. Last modified on 1 July 2014. http://www. tobaccotactics.org/index.php/Beneluxvereniging_voor_Merken-en_Modellenrecht (accessed 22 Jul 2014).

91 Tobacco Control Research Group. National Association of Manufacturers. University of Bath. Last modified on 12 March 2014. http://www.tobaccotactics.org/index. php/National_Association_of_Manufacturers (accessed 22 Jul 2014).

92 Tobacco Control Research Group. TransAtlantic Business Dialogue. University of Bath. Last modified on 29 August 2013. http://www.tobaccotactics.org/index.php/ TransAtlantic_Business_Dialogue (accessed 22 Jul 2014).

93 APRAM, BMM, ECTA, et al. Objection to the adoption of restrictive legislation or policy options frequently referred to as "generic" or "plain packaging". 23 April 2012. http://www.marques.org/Newsletters/Newsletter/Default.asp?NewsletterlD= $6 \&$ art $=0$ (accessed: 12 Jun 2013).

94 US Chamber of Commerce, TransAtlantic Business Dialogue, Emergency Committee for American Trade, et al. Business groups issues statement expressing deep concern following announcement by Her Majesty's Government that the United Kingdom is starting a public consultation to review the mandated destruction of trademarks and branding in the tobacco sector. 13 April 2012. http://www prnewswire.co.uk/news-releases/business-groups-issue-statement-expressing-deepconcern-following-announcement-by-her-majestys-government-that-the-unitedkingdom-is-starting-a-public-consultation-to-review-the-mandated-destruction-oftrademarks-and-branding-in-147327455.html (accessed 21 Jul 2014).

95 International Chamber of Commerce. ICC stresses need for wider perspective on plain packaging. 13 April 2012. http://www.prnewswire.co.uk/news-releases/iccstresses-need-for-wider-perspective-on-plain-packaging-147327435.html (accessed 21 Jul 2014).

96 International Chamber of Commerce Business Action to Stop Counterfeiting and Piracy. Plain packaging law creates dangerous precedent, statement of Director Jeffrey Hardy. 27 October 2011. http://bascap.iccccs.org/index.php?option=com_ flexicontent\&view=items\&cid=1:bascap-blog\&id=52:plainpackaging-law-createsdangerous-precedent\&ltemid $=1$

97 Federation of Wholesale Distributors. Standardised tobacco packaging in wholesale "will not achieve government's aims", say FWD. 17 April 2012. http://www. talkingretail.com/category-news/independent-news/standardised-tobaccopackaging-in-wholesale-will-not-achieve-governments-aims-says-fwd/ (accessed 12 Jun 2014).

98 Hands Off Our Packs. Newsroom: Stores fear plain packaging will major burden Association of Convenience Stores issues plea to Government. 17 April 2012. http://www.handsoffourpacks.com/index.php/newsroom/stores-fear-plainpackaging-will-major-burden/ (accessed 21 Jul 2014)

99 National Federation of Retail Newsagents. National Federation of Retail Newsagents response to the 'Future of Tobacco Control' consultation. 2008. http:// 
centrallobby.politicshome.com/fileadmin/epolitix/stakeholders/TobaccoConsultation. pdf (accessed 24 Nov 2013).

100 National Federation of Retail Newsagents and Scottish Grocers' Federation. Independent newsagents fear boost to illicit trade from plain tobacco packaging. 16 April 2012. http://www.talkingretail.com/category-news/independent-news/ independent-newspapers-fear-boost-to-illicit-trade-from-plain-tobacco-packaging/ (accessed 23 Nov 2013).

101 UNITE. Plain packaging for cigarettes is "counterfeiters' charter". 9 March 2011. http://archive.unitetheunion.org/news_events/archived_news_releases/2011_ archived_press_releases/plain_packaging_for_cigarettes.aspx (accessed 21 Jul 2014).

102 Long J. UNITE food, drink and tobacco: introduction to the sector. 2012. http:/l www.unitetheunion.org/how-we-help/list-of-sectors/food-drink-and-tobacco/ (accessed 21 Jul 2014)

103 Parkside-Flexibles, Chesapeake, Weidenhammer, et al. Plain packaging of tobacco products, letter to Mark Prisk MP, Minister of State for Business and Enterprise. For Release pursuant to the Freedom of Information Act 2000. 2 May 2012.

104 Mardle P. Manufacturers join forces to lobby plain packaging proposal. 20 June 2012. http://www.printweek.com/news/1137338/manufacturers-join-forces-lobbyplain-packaging-proposal/ (accessed 21 Jul 2014).

105 Lejeune J. Stakeholder consultations Tobacco Products Directive and comments ECMA on potential changes to the TPD. ECMA TPD Consultation Submission. 7 December 2010: For release pursuant to EC Regulation 1049/2001.

106 Blaschke A. Plain Packaging for cigarettes will ease counterfeiting, in European Voice. 10 May 2012: Brussels.

107 Tobacco Control Research Group. European Carton Makers Association. University of Bath. Last modified on 18 June 2014. http://www.tobaccotactics.org/index.php/ European_Carton_Makers_Association (accessed 23 Jul 2014).

108 Tobacco Control Research Group. Mike Ridgway. University of Bath. Last modified 8 July 2014. http://www.tobaccotactics.org/index.php/Mike_Ridgway (accessed 23 Jul 2014).

109 Paisley I, Brady G, Binley B, et al. Open Letter to Secretary of State, the Rt. Hon. Andrew Lansley MP signed by 51 MPs. 29 June 2012. http://www.order-order. com. Guido Fawkes' blog.

110 Tobacco Control Research Group. Japan Tobacco International: Hospitality for UK MPs. University of Bath. Last modified 18 May 2012. http://www.tobaccotactics. org/index.php/Japan_Tobacco_International:_Hospitality_for_UK_MPs (accessed 20 Jul 2014).

111 Bloomquist E. Global Tobacco: The plain risk to Global tobacco. Hamburg Berenberg Bank: 2011.

112 Tobacco Control Research Group. John Luik. University of Bath. Last modified 11 October 2012. http://www.tobaccotactics.org/index.php/John_Luik (accessed 17 Jun 2013).

113 Basham P, Luik J. Erasing intellectual property: "Plain packaging" for consumer products and the implications for trademark rights. Washington Legal Foundation: Washington, DC, 2011.

114 Ramm, R. 'Government plans for plain packaging will boost illicit trade.' The Huffington Post, United Kingdom, 2 July 2012. http://www.huffingtonpost.co.uk/ roy-ramm/plain-cigarette-packaging-government-plans-for-plai_b_1637528.html (accessed 18 November 2014)

115 Sheridan, P. 'Plans for plain packaging of cigarettes are a charter for organised crime and a danger to our children.' The Daily Mail Online, 22 June 2012. http:// www.dailymail.co.uk/debate/article-2163227/Plans-plain-packaging-cigarettescharter-organised-crime-danger-children.html (accessed 18 November 2014)
116 Millson S. Group Head of Corporate Affairs for British American Tobacco, Letter to Deborah Arnott. 20 May 2013, Action for Smoking and Health.

117 Montini T, Bero L. Policy makers' perspectives on tobacco control advocates' roles in regulation development. Tob Control 2001;10:218-24.

118 Quit Victoria. Analysis of KPMG LLP report on use of illicit tobacco in Australia 2013 Full year report. 2014. https://www.cancervic.org.au/downloads/plainfacts/ AnalyKPMGFull_year_2013.pdf (accessed 18 Jul 2014).

119 Quit Victoria. Illicit trade of tobacco in Australia: Report for 2011: a report prepared for British American Tobacco Australia Limited, Philip Morris Limited and Imperial Tobacco Australia Limited. 2012. Australia. https://www.cancervic.org.au/downloads/ plainfacts/CritiqueDeloitte_May_2012_Update_.pdf (accessed 18 Jul 2014).

120 Quit Victoria. Illicit trade of tobacco in Australia: A report prepared by Deloitte for British American Tobacco Australia Limited, Philip Morris Limited and Imperial Tobacco Australia Limited. 2011. Australia. https://www.cancervic.org.au/ downloads/plainfacts/CommtsDeloitte18_11_11_2_pdf (accessed 18 Jul 2014).

121 Gilmore AB, Rowell A, Gallus S, et al. Towards a Greater understanding of the illicit tobacco trade in Europe: a review of the PMI funded, KPMG authored "project star" report. Tob Control 2014;23:e51-61.

122 Rowell A, Evans-Reeves KA, Gilmore A. Tobacco industry manipulation of data and press coverage of the illicit tobacco trade in the UK. Tob Control 2014;23:e35-43.

123 van Welbeek C, Shai L. Are the tobacco industry's claims about the size of the illicit cigarette maket credible? The case of South Africa. Tob Control 2015;24: e142-6.

124 KPMG. Project Sun: a study of the illicit cigarette market in the European Union, 2013 results. 2014. http://www.pmi.com/eng/media_center/media_kit/Documents/ SUN\%20Report\%202013.pdf (accessed 23 Jul 2014).

125 Howell $F$. The Irish tobacco industry position on price increases on tobacco products. Tob Control 2012;21:514-16.

126 KPMG. Illicit tobacco in Australia: 2013 full year report. 12 April 2014.

127 Scollo M, Bayly M, Wakefield M. Availability of illicit tobacco in small retail outlets before and after the implementation of Australian packaging legislation. Tob Control 2015;24: e45-51.

128 Sparrow A. Anger as plain cigarette packaging plans put on hold by ministers, in The Guardian. 12 July 2013.

129 BBC. Government rejects Labour's cigarette 'u-turn' claim. 12 July 2013. http:/l www.bbc.co.uk/news/health-23281804 (accessed 3 Oct 2014).

130 BBC. Cigarette packaging: Ministers launch fresh review. 28 November 2013. http://www.bbc.co.uk/news/uk-politics-25126673 (accessed 3 Oct 2014).

131 Smith KE, Gilmore A, Fooks $\mathrm{G}$, et al. Tobacco industry attempts to undermine Article 5.3 and the "good governance" trap. Tob Control 2009;18:509-11

132 Drazen JM, Curfman GD. Financial associations of authors. N Engl I Med 2002;346:1901-2.

133 Fletcher R, Ferris L; World Association of Medical Editors Editorial Policy and Publication Ethics Committees. Conflict of interest in peer-reviewed medical journals. 2009. http://www.wame.org/conflict-of-interest-in-peer-reviewed-medicaljournals (accessed 29 Oct 2013).

134 Krimsky S, Rothenberg LS. Conflict of interest policies in science and medical journals: Editorial practices and author disclosures. Sci Eng Ethics 2001;7:205-18.

135 Tobacco Control Research Group. Alliance of Australian Retailers. University of Bath. Last modified on 25 September 2014. http://tobaccotactics.org/index.php/ Alliance_of_Australian_Retailers (accessed 24 Nov 2014)

136 Tobacco Control Research Group. The Common Sense Alliance. University of Bath. Last modified 22 August 2014. http://tobaccotactics.org/index.php/ The_Common_Sense_Alliance (accessed 24 Nov 2014). 